\title{
PERKEMBANGAN BANK SYARIAH DI INDONESIA: SEBUAH KAJIAN HISTORIS
}

\author{
M. Dliyaul Muflihin \\ UIN Sunan Ampel Surabaya \\ e-mail: mdliyaulmuflihin@gmail.com
}

\begin{abstract}
Banking in Indonesia is now increasingly enlivened by the existence of Islamic banks, which offer financial and investment products in different ways than conventional banks that have long existed. Even conventional banks in Indonesia are now following the trend by establishing their own Islamic institutions or Islamic business units. Recorded in 2012 Islamic banks have increased rapidly to become 11 Islamic Commercial Banks (BUS) and 24 Sharia Business Units (UUS). Islamic banks were born and developed in Indonesia starting from the birth of Bank Muamalat in 1992. Law Number 7 of 1992 concerning banking was born because in that year Bank Muamalah was the only bank that carried out business activities based on the principle of profit sharing. Furthermore, the culmination point has been reached with the enactment of Law Number 10 of 1998 concerning banking which opens the opportunity for anyone who will establish a Shari'ah bank or who wants to convert from a conventional system to a sharia system. Until the issuance of Law No.10 of 1998. Furthermore, Law No.10 of 1998 was amended by Law No. 21 of 2008 concerning Islamic banking because on June 172008 the Law on Islamic Banking was adopted which promulgated in the State Gazette on July 162008.
\end{abstract}

Keywords: History of Development, Islamic Banking, Indonesia

\section{Pendahuluan}

Perbankan di Indonesia kini makin diramaikan dengan adanya bank syariah, yang menawarkan produk keuangan dan investasi dengan cara yang berbeda dibanding bank konvensional yang sudah lama ada. Bahkan bank-bank konvensional di Indonesia kini ikutan tren dengan mendirikan institusi syariah atau unit usaha syariah sendiri. Tercatat di tahun 2012 bank syariah telah meningkat pesat hingga menjadi 11 Bank Umum Syariah (BUS) dan 24 Unit Usaha Syariah (UUS). ${ }^{1}$

Lahirnya bank syariah tersebut merupakan cikal bakal dari terbentuknya Lembaga Keungangan Syariah (LKS) di Indonesia pada tahun 1980-an dalam bentuk Lembaga Keuangan Mikro Syariah (LKMS), diawali dengan berdirinya Baitul Tamwil Teknosa di Bandung pada Tahun 1984 yang disusul dengan berdirinya Koperasi Ridho Gusti di Bandung pada tahun 1989, selain itu pada akhir 1980-an muncul pula BPR Syariah pertama. Bank syariah belum muncul pada waktu itu, karena undang-undang perbankan syariah yang berlaku saat itu adalah UU No. 13 Tahun 1967 yang mana UU tersebut belum mengakomodasi beroperasinya bank syariah. ${ }^{2}$ Pada awal tahun 1990-an bank syariah berdiri di Indonesia ditandai dengan berdirinya Bank Muamalat. Sampai tahun-tahun berikutnya perkembangan

\footnotetext{
${ }^{1}$ Pusat Riset dan Edukasi Bank Indonesia, Pengantar Kebanksentralan: Teori dan Praktik di Indonesia (Jakarata: Rajawali Pers, 2014), 376.

${ }^{2}$ Ibid., 370.
} 
bank syariah semkin pesat. Tidak hanya berkembang jumlah kantornya saja, juga berkembang persaingannya baik antara sesama bank syariah ataupu dengan bank konvensional.

Oleh karena itu, penulis hendak mengulas kembali bagaimana sejarah berdirinya bank syariah di Indonesia beserta legal standing dan market share bank syariah di Indonesia.

\section{Sejarah Bank Syariah}

Perkembangan bank-bank syariah di negara-negara Islam pada abad 19 memberi pengaruh terhadap Indonesia. Pada awal 1980-an, diskusi mengenai bank syariah sebagai pilar ekonomi Islam mulai dilakukan. Beberapa uji coba pada pada skala yang relatif terbatas telah diwujudkan seperti Baitut Tamwil Salman Bandung dan Koperasi Ridho Gusti Jakarta. Akan tetapi prakarsa lebi khusus untuk mendirikan Bank Islam di Indonesia baru dilakukan pada tahun 1990 berdasarkan keputusan dalam Lokakarya Musyawarah Nasional (Munas) IV MUI pada bulan Agustus 1990 di Jakarta. Berdasarkan amanat Munas IV MUI, dibentuklah kelompok kerja untuk mendirikan bank Islam di Indonesia. ${ }^{3}$

Hasil kerja Tim Perbankan MUI ditandai dengan berdirinya PT Bank Muamalat Indonesia Tbk yang didirikan pada 24 Rabius Tsani $1412 \mathrm{H}$ atau 1 Nopember 1991, diprakarsai oleh Majelis Ulama Indonesia (MUI) dan Pemerintah Indonesia, dan memulai kegiatan operasinya pada 27 Syawwal $1412 \mathrm{H}$ atau 1 Mei 1992. Dengan dukungan nyata dari eksponen Ikatan Cendekiawan Muslim se-Indonesia (ICMI) dan beberapa pengusaha Muslim, pendirian Bank Muamalat juga menerima dukungan masyarakat, terbukti dari komitmen pembelian saham perseroan senilai Rp 84 miliar pada saat penandatanganan akta pendirian perseroan. Selanjutnya, pada acara silaturahmi peringatan pendirian tersebut di Istana Bogor, diperoleh tambahan komitmen dari masyarakat Jawa Barat yang turut menanam modal senilai Rp 106 miliar. $^{4}$

Pada tanggal 27 Oktober 1994, hanya dua tahun setelah didirikan, Bank Muamalat berhasil menyandang predikat sebagai Bank Devisa. Pengakuan ini semakin memperkokoh posisi perseroan sebagai bank syariah pertama dan terkemuka di Indonesia dengan beragam jasa maupun produk yang terus dikembangkan.

Pada akhir tahun 90-an, Indonesia dilanda krisis moneter yang memporakporandakan sebagian besar perekonomian Asia Tenggara. Sektor perbankan nasional tergulung oleh kredit macet di segmen korporasi. Bank Muamalat pun terimbas dampak krisis. Di tahun 1998, rasio pembiayaan macet (NPF) mencapai lebih dari 60\%. Perseroan mencatat rugi sebesar Rp 105 miliar. Ekuitas mencapai titik terendah, yaitu Rp 39,3 miliar, kurang dari sepertiga modal setor awal.

Dalam upaya memperkuat permodalannya, Bank Muamalat mencari pemodal yang potensial, dan ditanggapi secara positif oleh Islamic Development Bank (IDB) yang berkedudukan di Jeddah, Arab Saudi. Pada RUPS tanggal 21 Juni 1999 IDB secara resmi menjadi salah satu pemegang saham Bank Muamalat. Oleh karenanya, kurun waktu antara tahun 1999 dan 2002 merupakan masa-masa yang penuh tantangan sekaligus keberhasilan bagi Bank Muamalat. Dalam kurun waktu tersebut, Bank Muamalat berhasil membalikkan kondisi dari rugi menjadi laba berkat upaya dan dedikasi setiap kru Muamalat, ditunjang oleh

\footnotetext{
${ }^{3}$ Muhammad Syafi'i Antonio, Bank Syariah dari Teori ke Praktek (Jakarta: Gema Insani, 2001), 25.

${ }^{4} \mathrm{http}: / /$ www.bankmuamalat.co.id/tentang/profil-muamalat Diakses pada tanggal 17 Agustus 2015.
} 
kepemimpinan yang kuat, strategi pengembangan usaha yang tepat, serta ketaatan terhadap pelaksanaan perbankan syariah secara murni.

Dari sejarah singkat di atas, perbankan syariah pada awalnya dikembangkan sebagai suatu respon dari kelompok ekonom dan praktisi perbankan muslim yang berupaya mengakomodasi desakan dari berbagai pihak yang menginginkan agar tersedia jasa transaksi keuangan yang dilaksanakan sejalan dengan nilai moral dan prinsip-prinsip islam. Utamanya adalah berkaitan dengan pelarangan praktik riba, kegiatan maysir (spekulasi), dan gharär (ketidakjelasan). Muhammad dalam bukunya menjelaskan bahwa bank syariah adalah bank yang beroprasi dengan tidak mengandalkan pada bunga dan produknya dikembangkan berlandaskan pada al-Quran dan Hadits Nabi Saw. ${ }^{5}$

Dari pemaparan di atas, Bank Muamalah merupakan bank syariah yang pertama kali lahir di Indonesia, hal itu menunjukkan terbukanya persaingan antara bank syariah dengan bank konvensional, karena lahirnya Bank Muamalat di Indonesia ini mendorong bank-bank lain membuka Unit Usaha Syariah (UUS) ataupun Badan Usaha Syariah (BUS).

\section{Legal Standing Bank Syariah}

Seiring dengan perkembangan UUS dan BUS, maka regulasi pun mengalami perkembangan ditandai dengan undang-undang tentang perbankan yang mengalami amandemen beberapa kali. Pada sekitar tahun 90-an Undang-undang Nomor 7 Tahun 1992 tentang perbankan lahir karena pada tahun tersebut Bank Muamalah sebagai satu-satunya bank yang melaksanakan kegiatan usaha berdasarkan primsip bagi hasil. Muhammad dalam bukunya menyebutkan bahwa posisi perbankan syariah semakin pasti setelah disahkannya Undang-Undang Perbankan No. 7 Tahun 1992 dimana bank diberikan kebebasan untuk menentukan jenis imbalan yang akan diambil dari nasabahnya, baik bunga ataupun keuntungan bagi hasil. Tetapi dengan terbitnya PP No 72 Tahun 1992 tentang bank bagi hasil yang secara tegas memberikan batasan bahwa "bank bagi hasil tidak boleh melakukan kegiatan usaha yang tidak berdasarkan prinsip bagi hasil (bunga), sebaliknya pula bank yang kegiatannya usahanya tidak berdasarkan prinsip bagi hasil tidak diperkenankan melakukan kegiatan usaha berdasarkan prinsip bagi hasil (Pasal 6). ${ }^{6}$

Selanjutnya titik kulminasi telah tercapai dengan disahkannya Undang-undang Nomer 10 Tahun 1998 tentang perbankan yang membuka kesempatan bagi siapa saja yang akan mendirikan bank syariah maupun yang ingin mengkonvesikan dari sistem konvensional menjadi sistem syariah. Uandang-undang ini sekaligus menghapus pasal 6 pada PP No. 72 tahun 1992 yang melarang dual system. ${ }^{7}$ Ini berarti kebujakan hukum perbankan di Indonesia menganut sistem perbankan ganda (dual banking system) Kebijakan ini intinya memberikan kesempatan bagi bank-bank umum konvensional untuk memberikan layanan syariah melalui mekanisme Islamic window dengan terlebih dahulu membentuk Unit Usaha Syariah (UUS). Akibatnya, pasca Undang-undang ini memunculkan banyak bank konvensional yang ikut andil dalam memberikan layanan syariah kepada nasabahnya.

\footnotetext{
${ }^{5}$ Muhammad, Manajemen Dana bank Syariah (Jakarta: PT. Raja Grafindo Persada, 2014), 2.

6 Muhammad Syafi'i Antonio, Bank Syari'ah: Analisis Kekuatan, Kelemahan, Peluang dan Ancaman (Yogyakarta: Ekonisia, 2002), 59.

${ }^{7}$ Ibid.
} 
Bank umum syariah (BUS) selain BMI, pasca Undang-Undang nomor 10 Tahun 1998 adalah didirikannya Bank Syariah Mandiri yang merupakan hasil akuisisi dan konversi PT. Bank Susila Bakti oleh PT. Bank Mandiri. Di samping itu, Bank Mega juga telah melakukan proses yang sama dengan membentuk PT. Bank Mega Syariah. Sedangkan bank-bank lain, seperti PT. Bank Rakyat Indonesia, PT. Bank Negara Indonesia, Bank Permata dan sebagainya dalam memberikan layanan syariah masih dalam kerangka UUS. ${ }^{8}$ Hingga terbitnya Undang-undang No. 10 tahun 1998, Indonesia telah melewati dua tahapan pembinaan, yaitu "tahapan perkenalan" (introduction) yang ditandai dengan diberlakukanya Undang-Undang No. 7 Tahun 1992, dan tahapan pengakuan (recognition) yang ditandai diberlakukanya UU No.10 Tahun 1998. Tahapan yang dikehendaki berikutnya adalah "tahapan pemurnian" (purification) yang nanti akan ditandai dengan diberlakukanya UU yang secara khusus mengatur perbankan syariah. ${ }^{9}$

Dengan demikian "tahapan pemurnian" saat ini sudah di depan mata, karena pada tanggal 17 Juni 2008 telah disahkan UU Perbankan Syariah yang pengundanganya dalam lembaran negara dilakukan tanggal 16 Juli 2008, yakni UU No 21 Tahun 2008 tentang perbankan syariah. Undang-undang dimaksud memperkenalkan beberapa muatan baru dalam lembaga hukum baru yang ditujukan untuk menunjang pelaksanaan pembangunan nasional dalam rangka meningkatkan keadilan, kebersamaan, dan pemerataan kesejahteraan rakyat.

\section{Produk-Produk Bank Syariah}

Pada sistem operasi bank syariah, pemilik dana menanamkan uangnya di bank tidak dengan motif mendapatkan bunga, tetapi dalam rangka mendapatkan keuntungan bagi hasil. Dana nasabah tersebut kemudian disalurkan kepada mereka yang membutuhkan (misalnya modal usaha), dengan perjanjian pembagian keuntungan sesuai kesepakatan. ${ }^{10}$

Secara garis besar, pengembangan produk bank syariah dibagi menjadi menjadi tiga kelompok, yaitu: ${ }^{11}$

1. Produk penyaluran dana

2. Produk penghimpunan dana

3. Produk jasa

Produk-produk tersebut yang ditawarkan bank kepada nasabahnya. Dengan penjelasan sebagai berikut:

1. Penyaluran dana ${ }^{12}$

a. Prinsip jual beli

Jual beli dilaksanakan karena adanya pemindahan kepemilikan barang. Keuntungan bank disebutkan di depan dan termasuk harga dari harga yang dijual. Terdapat tiga jenis jual beli dalam pembiayaan konsumtif, modal kerja dan investasi dalam bank syariah, yaitu:

\footnotetext{
${ }^{8} \mathrm{https} / / /$ smjsyariah89.wordpress.com/2012/05/06/sejarah-perkembangan-hukum-perbankan-syariah-di-indonesia/ Diakses pada 11 Maret 2017.

${ }^{9}$ Ibid.

${ }^{10}$ Muhammad, Manajemen Dana Bank Syariah, 28.

${ }^{11}$ Ibid., 29

12 Ibid.
} 
1) Ba'i al-murābahah: jual beli dengan harga asal ditambah keuntungan yang disepakati antara pihak bank dengan nasabah, dalam hal ini bank menyebutkan harga barang kepada nasabah yang kemudian bank memberikan laba dalam jumlah tertentu sesuai kesepakatan.

2) Ba'i al-salam: dalam jual beli ini nasabah sebagai pembeli dan pemesan member uangnya ditempat akad sesuai dengan harga barang yang dipesan dan sifat barang telah disebutkan sebelumnya. Uang yang diserahkan kepada bank menjadi tanggungan bank sebagai penerima pesanan dan pembayaran dilakukan dengan segera.

3) Ba'i al-istiṣnā': merupakan bagian dari ba'i al-salam namun ba'i al-istiṣnā', biasa digunakan dalam bidang manufaktur. Seluruh ketentuan ba'i al-istiṣna', mengikuti ba'i al-salam namun pembayaran dapat dilakukan beberapa kali pembayaran.

b. Prinsip sewa (ijärah)

Ijārah adalah kesepakatan pemindahan hak guna atas barang atau jasa melalui sewa tanpa diikuti pemindahan kepemilikan atas barang yang disewa.

c. Prinsip bagi hasil (syirkah)

Dalam prinsip bagi hasil terdapat dua macam produk, yaitu:

1) Mushärakah: adalah salah satu produk bank syariah yang mana terdapat dua pihak atau lebih yang bekerja sama untuk meningkatkan asset yang dimiliki bersama di mana seluruh pihak memadukan sumber daya yang mereka miliki baik yang berwujud maupun yang tidak berwujud.

2) Muḍarabah: adalah kerja sama dua orang atau lebih di mana pemilik modal memberikan kepercayaan sejumlah modal kepada pengelolah dengan perjanjian pembagian keuntungan. Perbedaan mendasar antara mushārakah dengan mudharabah adalah kontribusi atas manajemen dan keuangan pada mushārakah diberikan dan dimiliki oleh dua orang atau lebih, sedangkan pada mudāarabah modal hanya dimiliki satu pihak saja.

2. Penghimpunan dana ${ }^{13}$

Produk penghimpunan dana pada bank syariah meliputi giro, tabungan, dan deposito. Prinsip yang diterapkan dalam bank adalah:

a. Prinsip wadi'ah

Penerapan prinsip wadi'ah yang dilakukan adalah wadi'ah yad ḍamānah yang diterapkan pada rekening produk giro. Berbeda dengan wadi'ah yad amānah, di mana pihak yang dititipi (bank) bertanggung jawab atas keutuhan harta titipan sehingga ia boleh memanfaatkan harta titipan tersebut. Sedangkan pada wadi'ah yad amānah harta titipan tidak boleh dimanfaatkan oleh yang dititipi.

b. Prinsip muḍārabah

Dalam prinsip muḍarabah, penyimpan atau deposan bertindak sebagai pemilik modal sedangkan bank bertindak sebagai pengelola. Dana yang tersimpan kemudian oleh bank digunakan untuk melakukan pembiayaan, dalam hal ini apabila bank

${ }^{13}$ Ibid., 31. 
menggunakannya untuk pembiayaan, maka bank bertanggung jawab atas kerugian yang mungkin terjadi.

Berdasarkan kewenangan yang diberikan oleh pihak penyimpan, maka prinsip muḍārabah dibagi menjadi tiga bagian, yaitu:

1) Muḍārabah mutlaqah adalah bentuk kerjasama antara șạhib al-māl (penyedia dana) dengan muḍ̄arabah (pengelola) yang cakupannya sangat luas dan tidak dibatasi oleh spesifikasi jenis usaha, waktu, dan daerah bisnis. Penyedia dana melimpahkan kekuasaan yang sebesar-besarnya kepada muḍārib untuk mengelola dananya. Jadi bank memiliki kebebasan penuh untuk menyalurkan dana ke bisnis manapun yang diperkirakan menguntungkan.

2) Muḍārabah muqayyadah on balance sheet adalah akad muḍārabah yang disertai pembatasan penggunaan dana dari șạhib al-māl untuk investasi-investasi tertentu.

3) Muḍārabah muqayyadah off balance sheet. Jenis muḍārabah ini merupakan penyaluran dana muḍārabah langsung kepada pelaksanaan usahanya, dimana bank bertindak sebagai perantara (arranger) yang mempertemukan antara pemilik dana dengan pelaksana usaha. Pemilik dana dapat menetapkan syaratsyarat tertentu yang harus dipatuhi oleh bank dalam mencari bisnis (pelaksana usaha).

3. Jasa perbankan ${ }^{14}$

Pelayanan jasa bank merupakan produk jasa bank yang diberikan kepada nasabah untuk memenuhi kebutuhannya. Bank menawarkan produk jasa dengan tujuan untuk memberikan pelayanan kepada nasabah bank atau pihak lain yang memerlukannya. Pendapatan yang diperoleh bank yang berasal dari pendapatan atas produk jasa disebut dengan fee based income. Jasa perbankan syariah antara lain seperti wakālah, kafălah, hawālah, rahn, qarḍ.

\section{Perkembangan Bank Syariah di Indonesia}

Sejarah perkembangan perbankan syariah dunia periode antara tahun 1940 sampai periode tahun 1980 menurut Duddy Roesmara Donna disajikan sebagai berikut: ${ }^{15}$

Tabel 1.1

Perkembangan Bank Syariah Tahun 1940-1980

\begin{tabular}{|c|l|}
\hline Tahun & \multicolumn{1}{|c|}{ Keterangan } \\
\hline 1940 & $\begin{array}{l}\text { Rintisan bank syariah di Malaysia, untuk mengelola dana jamaah haji } \\
\text { secara non-konvensional. }\end{array}$ \\
\hline 1963 & Berdirinya Mit Ghamr Real Bank di Mesir, oleh Dr. Ahmad Najar. \\
\hline 1967 & $\begin{array}{l}\text { Mit Ghamr ditutup arena alasan politis dan diambil alih oleh National } \\
\text { Bank of Egypt. }\end{array}$ \\
\hline 1969 & Muncul gagasan kolektif pembentukan Bank Syari'ah pada Konferensi \\
\hline
\end{tabular}

\footnotetext{
${ }^{14}$ Ismail, Perbankan Syariah (Jakarta: Kencana, 2011), 193.

${ }^{15}$ Duddy Roesmara Donna, "Perbankan Syariah (1), Buletin ekonomika dan Bisnis Islam, Edisi II/V (25 Mei 2007), 3-4.
} 


\begin{tabular}{|c|l|}
\hline & Negara-negara Islam se-dunia di Malaysia. \\
\hline 1970 & $\begin{array}{l}\text { Delegasi Mesir mengajukan proposal pendirian Bank Syariah pada Sidang } \\
\text { Menteri Luar Negeri Negara-negara OKI di Karachi. }\end{array}$ \\
\hline 1972 & $\begin{array}{l}\text { Berdiri kembali sistem bank tanpa bunga yang bersifat sosial di Mesir, } \\
\text { yaitu Nasser Social Bank. }\end{array}$ \\
\hline Maret 1972 & $\begin{array}{l}\text { Usulan/proposal Delegasi Mesir diagendakan kembali dan memutuskan } \\
\text { membentuk komisi khusus menangani masalah ekonomi dan keuangan. }\end{array}$ \\
\hline Juli 1973 & $\begin{array}{l}\text { Para ahli yang mewakili Negara Islam penghasil minyak membicarakan } \\
\text { Pendirian Bank Syari'ah dan terumuskanlah Anggaran Dasar dan } \\
\text { Anggaaran Rumah Tangga. }\end{array}$ \\
\hline Mei 1974 1974 & $\begin{array}{l}\text { Pembahasan AD/ART yang telah dirumuskan. } \\
\text { serdiri Islamic Development Bank dengan modal awal 2 miliar Dinar atau }\end{array}$ \\
\hline Awal 1980-angan 2 miliar SDR (Special Drawing Rights) IMF. \\
\hline $\begin{array}{l}\text { Bermunculan Lembaga Keuangan Syari'ah di Mesir, Sudan, negara- } \\
\text { negara di wilayah Teluk, Malaysia, Pakistan, Inggris, Denmark, Bahmas, } \\
\text { Swiss dan Luxembourg. }\end{array}$ \\
\hline
\end{tabular}

Terkait dengan perkembangan perbankan syariah di Indonesia periode tahun 1970 sampai dengan tahun 2003, menurut Duddy Roesmara Donna dapat dirunut melalui kronologis sebagai berikut: ${ }^{16}$

Tabel 1.2

Perkembangan Bank Syariah 1970-2003

\begin{tabular}{|c|c|}
\hline Tahun & Keterangan \\
\hline 1970-an & Muncul gagasan pendirian Bank Syariah \\
\hline 1988 & $\begin{array}{l}\text { Muncul lagi gagasan Bank Syari'ah karena pemerintah mengeluarkan } \\
\text { Paket Kebijakan Oktober (Pakto) yang berisi liberalisasi industri } \\
\text { perbankan. Namun, gagasan tersebut deadlock karena tidak ada perangkat } \\
\text { hukum yang dapat menjadi rujukan. }\end{array}$ \\
\hline $\begin{array}{l}\text { 19-22 Agustus } \\
1990\end{array}$ & Lokakarya Ulama tentang bunga bank dan perbankan di Cisarua Bogor. \\
\hline $\begin{array}{l}\text { 22-25 Agustus } \\
1990\end{array}$ & $\begin{array}{l}\text { Pembahasan hasil lokakarya pada Munas IV MUI di Jakarta dan } \\
\text { terbentuklah Kelompok Kerja Pembentukan Bank Syariah. }\end{array}$ \\
\hline $\begin{array}{l}1 \text { November } \\
1991\end{array}$ & $\begin{array}{l}\text { Penandatanganan Akte Pendirian Bank } \text { Muamalat Indonesia } \\
\text { terkumpulah komitmen pembelian saham sebanyak } 84 \text { miliar. }\end{array}$ \\
\hline $\begin{array}{l}3 \text { November } \\
1991\end{array}$ & $\begin{array}{l}\text { Silaturrahim dengan presiden di Istana Bogor dan Terpenuhilah komitmen } \\
\text { modal disetor awal sebesar Rp.106.126.382.000. }\end{array}$ \\
\hline 1 Mei 1992 & Operasional awal Bank Muamalat Indonesia (BMI). \\
\hline 1992 & $\begin{array}{l}\text { Pengakomodasian perbankan dengan prinsip bagi hasil pada Undang- } \\
\text { Undang No. } 7 \text { Tahun } 1992 \text { tentang Perbankan. }\end{array}$ \\
\hline 1992 & Pengenalan dual banking system. \\
\hline $\begin{array}{l}30 \text { Oktober } \\
1992\end{array}$ & $\begin{array}{l}\text { Peraturan Pemerintah (PP) No. } 72 \text { Tahun } 1992 \text { tentang bank berdasarkan } \\
\text { prinsip bagi hasil. }\end{array}$ \\
\hline
\end{tabular}

16 Ibid. 


\begin{tabular}{|c|l|}
\hline $\begin{array}{c}29 \text { Februari } \\
1993\end{array}$ & $\begin{array}{l}\text { PP tersebut dijabarkan secara terperinci dengan keluarnya Surat Edaran BI } \\
\text { No.25/4/BPPP. }\end{array}$ \\
\hline 1994 & $\begin{array}{l}\text { BMI men-sponsori berdiriya Asurasi Syariah, Syarikat Tafakul Indonesia } \\
\text { dan menjadi salah satu pemegang sahamnya. }\end{array}$ \\
\hline 1997 & $\begin{array}{l}\text { BMI mensponsori lokakarya Ulama tentang Reksadana Syariah yang } \\
\text { diikuti operasionalnya dengan dikelola oleh PT. Danareksa Investment } \\
\text { Management. }\end{array}$ \\
\hline 1998 & $\begin{array}{l}\text { Undang-Undang No. 10 Tahun 1998 tentang Perbankan, merubah } \\
\text { Undang-Undang No. 7 Tahun 1992 yang mengakomodasi perkembangan } \\
\text { perbankan secara lebih luas. }\end{array}$ \\
\hline 1999 & Kebijakan moneter berdasarkan prinsip syariah. \\
\hline 2000 & Keluarnya regulasi operasional dan kelembagaan. \\
\hline 2001 & Pendirian Biro Perbankan Syariah Bank Indonesia. \\
\hline September 2003 & $\begin{array}{l}\text { Perubahan Biro Perbankan Syariah menjadi Direktorat Perbankan Syariah } \\
\text { BI. }\end{array}$ \\
\hline
\end{tabular}

Statistik perbankan syariah yang dirilis oleh Bank Indonesia menunjukkan bahwa sampai dengan bulan November tahun 2007, jumlah bank syariah mencapai 143 bank. Dari ke 143 bank tersebut, 3 di antaranya merupakan Bank Umum Syariah (BUS), dan 26 bank diantaranya merupakan Unit Usaha Syariah (UUS), serta 114 sisanya merupakan Bank Perkreditan Rakyat Syariah (BPRS). Terkait dengan kondisi saat ini, diperkirakan pertumbuhan bank umum syariah, unit usaha bisnis syariah (unit bisnis bank konvensional), maupun bank perkreditan rakyat syariah, meningkat. Artinya jumlah bank syariah naik dari tahun ke tahun.

Produk dan jasa perbankan syariah di Indonesia diberikan oleh (1) Bank Umum Syariah (BUS); (2) Unit Usaha Syariah (UUS) yang merupakan unit kerja dari bank konvensional yang sepenuhnya dioperasikan secara syariah dan terpisah; (3) Office Channeling (OC) yang merupakan konter syariah dari UUS di kantor cabang induk konvensionalnya. Data statistik menyebutkan bahwa pada tahun 2012 bank syariah telah meningkat pesat hingga menjadi 11 BUS dan 24 UUS dengan 2.663 buah kantor dan 1277 buah OC. ${ }^{17}$

\section{Market Share Bank Syariah}

Dikutip dari Koran Jakarta, dituliskan bahwa perkembangan industri perbankan syariah masih lambat meskipun potensinya sangat besar. Salah satu penyebabnya produk syariah dinilai masih kalah kompetitif dibandingkan konvensional. Ironisnya, penguasaan pasar atau market share bank syariah di industri perbankan nasional masih kalah jauh dengan bank konvensional. Market share bank syariah di Indonesia baru 5,0 persen. saat ini tercatat 12 perbankan syariah di Indonesia. Sebanyak enam bank masuk dalam kategori Bank Umum Kelompok Usaha (BUKU) I atau modal kurang dari 1 triliun rupiah, sedangkan sisanya di BUKU 2 dengan modal 1,5 triliun rupiah. SEVP Finance and Strategy Bank Mandiri Syariah (BSM), Ade Cahyo Nugroho menilai potensi bank syariah di Indonesia sangat besar mengingat sekitar 85 persen penduduknya muslim. Menurut Ade, rendahnya penguasaan

\footnotetext{
${ }^{17}$ Pusat Riset dan Edukasi Bank Indonesia, Pengantar Kebanksentralan, 376.
} 
pasar perbankan syarian disebabkan sejumlah kendala. "Ini karena banyak faktor, seperti sosialisasi dan produk yang kurang kompetitif'. ${ }^{18}$

Terkait dengan itu, dalam membentuk positioning product atau merek, Kotler menyebutkan bahwa perusahaan haruslah merancang penawaran dan citra perusahaan agar mendapatkan tempat khusus dalam pikiran pasar, tujuannya adalah untuk menempatkan merek produk dalam pikiran konsumen dan memaksimalkan manfaat potensi bagi perusahaan. ${ }^{19}$

Selain itu dalam meningkatkan market share bank syariah perlu melakukan kebijakan branchless banking, yaitu bank menjangkau unbanked people dan masyarakat di remote area untuk menerima layanan perbankan. ${ }^{20} \mathrm{Di}$ sinilah peran branchless banking mulai mengemuka sebagai bagian dari upaya menjangkau masyarakat untuk "berbank". Apabila untuk membuka kantor cabang bank di daerah pelosok untuk menjangkau kegiatan ekonomi masyarakat marginal masih dianggap terlalu mahal, maka salah satu solusinya adalah branchless banking. Dengan cara: ${ }^{21}$

1. Penyediaan produk dan jasa keuangan yang sesuai. Misalnya tabungan yang tidak habis oleh biaya administrasi atau kredit bersifat harian atau mingguan.

2. Penyediaan infrastruktur sarana penyampaian jasa keuangan yang sesuai. Misalnya melalui penggunaan jasa pihak ketiga yang berada di sekitar masyarakat tersebut atau penggunakan teknologi telekomunikasi.

3. Peningkatan perlindungan konsumen dan edukasi keuangan untuk meningkatkan literasi keuangan masyarakat.

Sehingga sosialisasi tentang bank syariah semakin meluas. Dan pada akhirnya masyarakat secara luas mengenal dan mau untuk "berbank" di bank syariah.

\section{Kesimpulan}

Dari paparan di atas, dapat disimpulkan bahwa:

1. Bank syariah lahir dan berkembang di Indonesia berawal dari lahirnya Bank Muamalat pada tahun 1992.

2. Undang-Undang Nomor 7 Tahun 1992 tentang perbankan lahir karena pada tahun tersebut Bank Muamalah sebagai satu-satunya bank yang melaksanakan kegiatan usaha berdasarkan prinsip bagi hasil. Selanjutnya titik kulminasi telah tercapai dengan disahkannya Undang-Undang Nomor 10 Tahun 1998 tentang Perbankan yang membuka kesempatan bagi siapa saja yang akan mendirikan bank syariah maupun yang ingin mengkonvesikan dari system konvensional menjadi sistem syariah. Hingga terbitnya Undang-Undang No. 10 tahun 1998. Selanjutnya Udang-Undang No. 10 tahun 1998 diamandemen dengan UU No. 21 Tahun 2008 tentang Perbankan Syariah karena pada

\footnotetext{
$18 \mathrm{http} / /$ www.koran-jakarta.com/perkembangan-perbankan-syariah-masih-lambat/ edisi 22/12/2016. Diakses pada 12 Maret 2017.

${ }_{19}$ Philip Kotler, Manajemen Pemasaran (Jakarta: Erlangga, 2008), 292.

20 Pungky Purnomo Wibowo, "Branchless Banking Setelah Multilicense: Ancaman Atau Kesempatan Bagi Perbankan Nasional" disampaikan dalam rangka memenuhi salah satu persyaratan Sekolah Staf Pimpinan Bank Indonesia (SESPIBI) Angkatan XXXI), 75.

${ }_{21}$ http://www.lppi.or.id/index.php/module/Editorial/id/branchless-banking-model-keuangan-inklusif. Diakses pada 11 Maret 2017.
} 
tanggal 17 Juni 2008 telah disahkan UU perbankan syariah yang pengundanganya dalam lembaran Negara dilakukan tanggal 16 Juli 2008.

3. Secara garis besar, pengembangan produk bank syariah dibagi menjadi menjadi tiga kelompok, yaitu produk penyaluran dana, produk penghimpunan dana dan produk jasa.

4. Solusi market share bank syariah yang dinilai lambat adalah dengan menerapkan brancless banking, yaitu bank menjangkau unbanked people dan masyarakat diremote area untuk menerima layanan perbankan.

\section{Daftar Rujukan}

Antonio, Muhammad Syafi'i. Bank Syariah dari Teori ke Praktek. Jakarta: Gema Insani, 2001.

Bank Syari'ah: Analisis Kekuatan, Kelemahan, Peluang dan Ancaman. Yogyakarta: Ekonisia, 2002.

Donna, Duddy Roesmara. "Perbankan Syariah" dalam Buletin ekonomika dan Bisnis Islam, Edisi II/V (25 Mei 2007).

Ismail. Perbankan Syariah. Jakarta: Kencana, 2011.

Kotler, Philip. Manajemen Pemasaran. Jakarta: Erlangga, 2008.

Muhammad. Manajemen Dana Bank Syariah. Jakarta: PT. Raja Grafindo Persada, 2014.

Pusat Riset dan Edukasi Bank Indonesia, Pengantar Kebanksentralan: Teori dan Praktik di Indonesia. Jakarata: Rajawali Pers, 2014.

Wibowo, Pungky Purnomo. Branchless Banking Setelah Multilicense: Ancaman Atau Kesempatan Bagi Perbankan Nasional, disampaikan dalam rangka memenuhi salah satu persyaratan Sekolah Staf Pimpinan Bank Indonesia (SESPIBI) Angkatan XXXI.

http://www.bankmuamalat.co.id/tentang/profil-muamalat

https://smjsyariah89.wordpress.com/2012/05/06/sejarah-perkembangan-hukum-perbankansyariah-di-indonesia/.

http://www.koran-jakarta.com/perkembangan-perbankan-syariah-masih-lambat/edisi 22/12/2016.

http://www.lppi.or.id/index.php/module/Editorial/id/branchless-banking-model-keuanganinklusif 